\title{
Pengaruh Struktur Kepemilikan, Ukuran Perusahaan dan Kebijakan Dividen pada Manajemen Laba Riil
}

\author{
I Wayan Budi ${ }^{1}$ \\ I G. A. M. Asri Dwija Putri \\ ${ }^{1}$ Fakultas Ekonomi dan Bisnis Universitas Udayana (Unud), Bali, Indonesia \\ email: iwayanbudi0@gmail.com / telp:082339248015 \\ ${ }^{2}$ Fakultas Ekonomi dan Bisnis Universitas Udayana (Unud), Bali, Indonesia
}

\begin{abstract}
ABSTRAK
Praktek manajemen laba riil dapat menunjukkan kinerja yang baik dalam jangka yang pendek, namun dalam jangka panjang dapat menurunkan nilai perusahaan. Tiga proksi manajemen laba riil adalah pengelolaan penjualan, produksi yang berlebihan dan pengurangan biaya diskresioner. Penelitian ini dilakukan untuk mendapatkan bukti empiris mengenai pengaruh struktur kepemilikan, ukuran Perusahaan dan kebijakan dividen pada manajemen laba riil. Penelitian ini dilakukan diperusahaan manufaktur yang terdaftar di Bursa Efek Indonesia (BEI) periode 2013-2016. Metode penentuan sampel yang digunakan adalah menggunakan purposive sampling. Teknik Analisis data yang digunakan yaitu regresi linear berganda. Berdasarkan hasil analisis ditemukan bahwa kepemilikan institusional tidak berpengaruh signifikan padamanajemen laba riil. Kepemilikan manajerial tidak berpengaruh signifikan pada manajemen laba riil. Ukuran Perusahaan berpengaruhi signifikan pada manajemeni laba riil dan kebijakan dividen berpengaruhi signifikan pada manajemen laba riil.
\end{abstract}

Kata Kunci: Manajemen laba riil, Struktur kepemilikan, ukuran Perusahaandan kebijakan dividen

\begin{abstract}
Real earnings management practices can show a good performance in the short term, but in the long term can reduce the value of the company. Three proxy real earnings management is sales manipulation, overproduction and reductions of discretionary expenditures. This study was conducted to obtain empirical evidence about the influence of the ownership structure, company size and dividend policy on real earnings management. This research was conducted in the company listed on the Indonesia Stock Exchange (BEI) in the period 2013-2016. The sampling method used was purposive sampling. Data analysis used is multiple linear regression. Based on the analysis found that institutional ownership has no significant effect on the real earnings management. Managerial ownership has no significant effect on the real earnings management. The size of the company a significant effect on the real earnings management and dividend policy have a significant effect on the real earnings management.

Keywords: real earnings management, ownership structure, company size and dividend policy
\end{abstract}

\section{PENDAHULUAN}

Pertumbuhan domestik Indonesia mengalami perkembangan yang pesat khususnya pada sektor manufaktur dari tahun 2013-2016. Berdasarkan adanya peningkatan permintaan produksi maka investor tertarik untuk menginvestasikan 
dananya dalam perusahaan. Investor dapat mengetahui kinerja perusahaan dari laporan keuangan. Laporan keuangan adalah sumber informasi perusahaan bagi pihak luar. Pernyataan Standar Akuntansi Keuangan (PSAK)I No. 1 (2015:2) menyatakan bahwa laporan keuangan merupakan suatu bagian dari pelaporan keuangan.

Laporan keuangan disusun melibatkan dua pihak. Pihak yang terlibat adalah pihak eksternal (luar) dan pihak internal (dalam). Laporan keuangan digunakan oleh pihak eksternal untuk membuat keputusan investasi. Sedangkan bagi pihak internal laporan keuangan digunakan untuk melihat perkembangan perusahaan. Setiap perusahaan yang sudah go public wajib mempublikasikan laporan keuangan ke pihak esternal (Gunawan, 2015).

Watts and Zimmerman (1990) menyatakan bahwa manajemen laba dapat dipandang sebagai perilaku oportunistik manajemen perusahaan untuk memaksimalkan kepentingannya terkait kontrak kompensasi, perjanjian utang, maupun biaya politik. Manajemen laba juga dapat dipandang dari persepktif efisiensi ketika manajemen perusahaan memiliki fleksibilitas untuk mengantisipasi dan melindungi perusahaan dari kejadian yang tak terduga dimasa mendatang, serta untuk melindungi pihak-pihak yang terkait didalamnya. Dengan harapan dapat membawa pengaruh yang lebih baik terhadap perusahaan (Octavia, 2015).

Banyak penelitian manajemen laba hanya berfokus pada manajemen laba berbasis akrual. Pratiwi (2013) dan (Kusumawati, 2015) menyatakan bahwa terjadi pergesaran dari manajemen laba akrual ke manajemen laba riil. Faktor 
yang mempengaruhi. Pertama,manajemen laba akrual sering digunakan sebagai pusat pengamatan oleh auditor. Kedua, risiko yang muncul akibat dilakukannya manajemen laba akrual jika realisasi akhir tahun defisit antara laba yang dimanipulasi dengan target laba yang diinginkan. Ketiga, manajemen laba riil lebih sulit untuk dideteksi oleh auditor.

Definisi dari manajemen laba riil adalah penyimpangan aktivitas operasi normal perusahaan. Manajemen memberikan pemahaman yang salah kepadapihak luar (Wijayanti, 2014). Adapuni proksi manajemen laba riil yaitu; arus kas operasi, biaya produksi, dan pengurangan biaya diskresioner. Manajemen laba riil melalui arus kas operasi dilakukan dengan pengelolaan penjualan dengan pemberian diskon dan kelonggaran jatuh tempo. Manajemen laba riil melalui biaya produksi dilakukan dengan produksi yang berlebihan, sehingga menurunkan harga pokok penjualan. Manajemen laba riil melaluibiaya diskresioner dilakukan melalui pengurangan biaya diskresioner yang meliputi biaya iklan, biayai riset dan pengembangan, biaya penjualan dan biaya administrasi umum (Vajriyanti, 2015).

Teori keagenan menurut (Jensen and Meckling, 1976) menjelaskan bahwa hubungan antara pemegang saham sebagai principal dan manajemen sebagai agent. Manajemen merupakan pihak yang ditunjuk oleh pemegang saham untuk bekerja demi kepentingan pemegang saham, sehingga mendapat wewenang dalam pengambilan keputusan dan mempertanggungjawabkan semua keputusan yang telah diambil oleh pemegang saham.

Pengawasan dan evaluasi perilaku manajer dapat mengeluarkan biaya disebut dengan agency cost, biaya ini dikeluarkan oleh pemegang saham. Untuk 
I Wayan budi dan IGA.M Asri Dwija Putri. Pengaruh...

mengurangi agency cost dapat dilakukan dengan meningkatkan kepemilikan manajerial. Langkah ini ditempuh dengan memberikan kesempatan kepada manajer untuk terlibat dalam kepemilikan saham. Keterlibatan kepemilikan saham manajerial membuat manajer bertindak dengan mempertimbangkan segala risiko yang ada. Dengan peningkatan kepemilikan manajerial maka manajemen laba dapat dikurangi (Mahariana, 2014).

Kepemilikan institusional juga diduga mampu memberikan mekanisme pengawasan serupa dalam perusahaan. Kepemilikan institusional merupakan saham perusahaan yang dimiliki oleh institusi atau lembaga. Investor institusional dapat melakukan pengawasan secara aktif karena investor institusional cenderung berinvestasi dalam jumlah yang sangat besar sehingga pengawasan yang dilakukan tentunya lebih aktif (Wiranata dan Nugrahanti, 2013). Kepemilikan institusional yang besar dapat mengurangi praktek manajemen laba.

Manajemen dapat mengetahui besar kecilnya ukuran Perusahaanmelalui total aset yang dimiliki oleh perusahaan. Menurut (Gunawan, 2015) bahwa ukuran Perusahaan memiliki hubungan positif dengan manajemen laba, karena perusahaan besar memiliki aktivitas operasional yang lebih kompleks dibandingkan perusahaan kecil, sehingga lebih memungkinkan untuk melakukan manajemen laba. Muliati (2011) serta Jao dan Pagalung (2011) menemukan bahwa ukuran Perusahaan berpengaruh negatif terhadap manajemen laba. Rahmani (2013) menemukan bahwa ukuran Perusahaan berpengaruh positif terhadap manajemen laba. 
Kebijakan dividen merupakan suatu keuntungan perusahaan yang dibayarkan kepada pemegang saham. Keuntungan yang didapat oleh perusahaan sebagian menjadi hak pemegang saham. Keuntungan yang tidak dibagikan sebagai dividen dapat dikatakan sebagai laba ditahan. Kebijakan dividen dikatakan sebagai motivasi manajer untuk melakukan manajemen laba, karena kebijakan dividen ditentukan oleh Rapat Umum Pemegang Saham (RUPS) dan tidak keputusan dari manajemen (Putri, 2012). Kebijakan tersebut dapat menimbulkan konflik kepentingan antara pemegang saham dan pihak manajer. Pihak manajer menginginkan menyimpan laba ditahan sebagai cadangan, sedangkan pemegang saham menginginkan dividend payout ratio (DPR) yang tinggi. Dengan demikian, kebijakan dividen menjadi sumber konflik antara manajemen dan pemegang saham.

Kebijakan dividen berpengaruh terhadap alirandana, struktur finansial, likuiditas perusahaan dan prilaku investor. Dengan demikian kebijakan dividen merupakan hal penting dalam kaitannya dengan usaha untuk meningkatkan nilai perusahaan (Wiagustini, 2014:286). Semakin besar laba ditahan maka semakin sedikit jumlah laba yang dialokasikan untuk pembayaran dividen. Untuk mengukur pembayaran dividen dilihat dari dividend payout ratio (DPR). Rasio pembayaran dividen (dividend payout rasio) menentukan jumlah laba yang ditahan dalam perusahaan sebagai sumber pendanaan. Dividend payout ratio yang tinggi membuat calon investor tertarik untuk menginvestasikan dananya dalam perusahaan tersebut. 
I Wayan budi dan IGA.M Asri Dwija Putri. Pengaruh...

Berdasarkan latar belakang di atas, peneliti tertarik untuk melakukan penelitian tentang pengaruh struktur kepemilikan, ukuran Perusahaan dan kebijkan dividen pada manajemen laba riil. Rumusan masalah yang dapat dipaparkan yaitu bagaimana pengaruh kepemilikan institusional pada manajemen laba riil?, bagaimana pengaruh kepemilikan manajerial pada manajemen laba riil?, bagaimana pengaruh ukuran Perusahaan pada manajemen laba rii? dan bagaimana pengaruh kebijakan dividen pada manajemen laba riil?.

Manfaat penelitian ini adalah menambah referensi, informasi, dan wawasan serta memberikan pemahaman yang lebih luas terkait pengaruh struktur kepemilikan, ukuran perusahaan dan kebijakan dividen pada manajemen laba riil. Hasil penelitian dapat digunakana sebagai acuan dalam pengambilan keputusan dalam berinvestasi.

Laporan keuangan adalahsuatu sumber informasimengenaikondisi perusahaan. Berdasarkan pernyataan PSAK No. 1 (2015:2) bahwa laporan keuangan terdiri atas neraca, laporan laba rugi, laporan perubahan posisi keuangan. Laporan keuangan disusun melibatkan dua pihak yaitu pihak internal dan eksternal. Laporan keuangan digunakan oleh pihak eksternal untuk mengambil keputusan investasi. Sedangkan bagi pihak internal laporan keuangan digunakan untuk melihat perkembangan perusahaan dari periode ke periode. Setiap perusahaan yang sudah go public wajib melaporkan laporan keuangan ke pihak eksternal (Gunawan, 2015).

Manajemen sering melakukan manipulasi laporan keuangan khususnya pada laba, hal ini sering disebut dengan tindakan manajemen laba. Menurut Watts 
and Zimmerman (1990) menyatakan bahwa manajemen laba dipandang sebagai tindakan manajemen untuk kepentingan kontrak kompensas, perjanjian utang, maupun biaya politik. Dampak postif dari manajemen laba menurut Octavia (2015) adalah melindungi perusahaan dari kejadian yang tidak terduga dimasa mendatang.

Adapun kerangka konseptual dalam penelitian ini menunjukkan pengaruh antar variabel dalam penelitian. Kerangka konseptual dalam penelitian ini disajikan pada gambar 1 sebagai berikut.

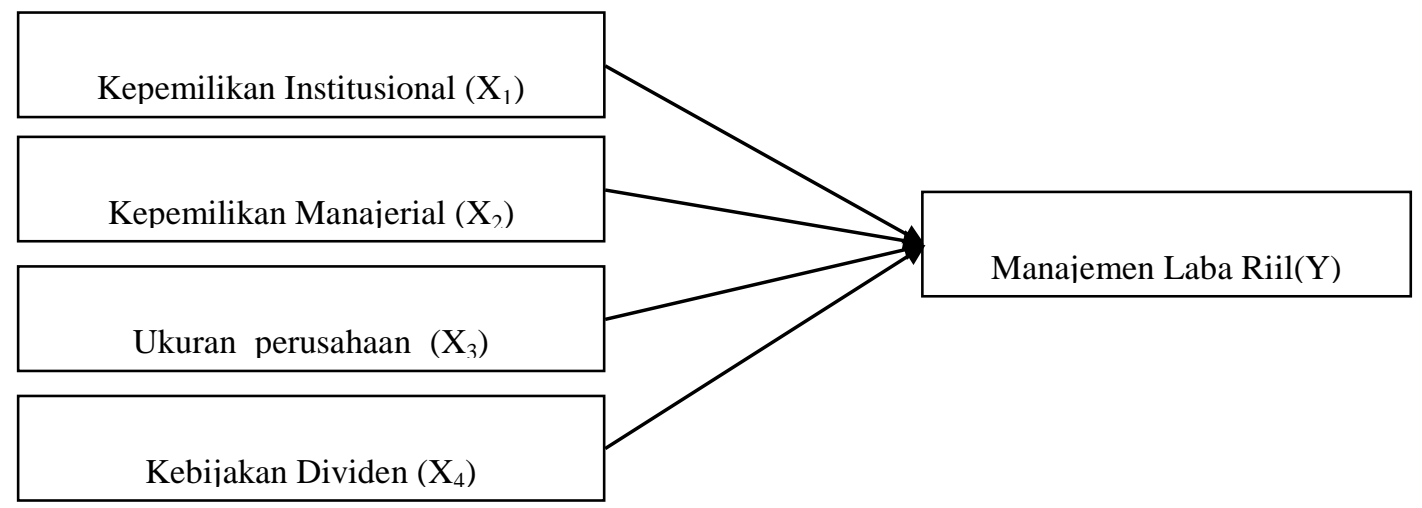

Gambar 1. Kerangka Konseptual

Menurut Jensen and meckling (1976) kepemilikan institusional merupakan kepemilikan saham yang dimiliki oleh pihak lembaga institusi. Utari menyatakan bhawa kepemilikan institusional merupakan pemegang saham yang memiliki pengaruh besar terhadap perusahaan kareana kepemilikan sahamnya yang besar. Rahmawati (2012: 186) menyatakan bahwa kepemilikan institusional perusahaan mendorong peningkatan pengawasan terhadap kinerja perusahaan. Semakin besar kepemilikan institusional maka tingkat pengawasan terhadap manajemen semakin kuat juga. 
I Wayan budi dan IGA.M Asri Dwija Putri. Pengaruh...

Hasil yang didapat dari penelitian Hsu (2015) dan Hidayanti (2014) menyatakan bahwa kepemilikan institusional berpengaruh negatif signifikan terhadap manajemen laba riil. Kepemilikan institusional tidak berpengaruh pada manajemen laba, hal ini mengindikasikan banyak atau sedikitnya hak suara yang dimiliki oleh institusi tidak dapat mempengaruhi tingkat besar kecilnya manajemen laba yang dilakukan oleh manajemen Mahariana (2014). Berbeda dengan penelitian Kusumawati (2015), Susanto (2016) dan Kamran (2014) Menyatakan bahwa kepemilikan institusional berpengaruh terhadap manajemen laba riil. Maka dapat dirumuskan hipotesis sebagai berikut:

$\mathrm{H}_{1}$ : Kepemilikanin stitusional berpengaruhi negatif pada menajemen labai riil.

Kepemilikan manajerial merupakan kepemilikan saham yang dimiliki oleh manajemen dalam perusahaan. Mahariana (2014) menyatakan bahwa presentase kepemilikan saham oleh manajemen cenderung mempengaruhi tindakan manajemen laba. Dengan memperbesar kepemilikan manajerial maka konflik keagenan dapat dikurangi. Manajemen yang mempunyai saham dalam perusahaan memiliki peran ganda yaitu sebagai pemegang saham dan sebagai pengelola perusahaan.

Jensen and meckling (1976) menyatakan bahwa kepemilikan manajerial dapat mengurangi konflik keagenan dalam perusahaan. Mahariana (2014) dan Susanto (2016) mendapatkan hasil bahwa kepemilakn manajerial berpengaruh negatif pada manajemen laba. Penelitian yang dilakukan oleh Kusumawati (2015), Hidayanti (2014) dan Pasaribu (2016) menemukan hasil yang positif antara 
kepemilikan manajerial terhadapmanajemenlabariil. Makadapatdirumuskan hipotesis sebagaiberikut:

$\mathrm{H}_{2}$ : Kepemilikan manajerial berpengaruh negatif pada manajemen laba riil.

Menurut Pasaribu (2016) bahwa ukuran Perusahaan merupakan suatu yang digunakan untuk mengetahui apakah perusahaan memiliki aktivitas operasional yang lebih kompleks. Perusahaan yang berukuran besar terkadang berada dibawah pengawasan berbagai kelompok, seperti pemerintah, kelompok karyawan, konsumen dan kelompok lingkungan. Muliati (2011) serta Jao dan Pagalung (2011) menemukan bahwa ukuran Perusahaanberpengaruh negatif terhadap manajemen laba. (Rahmani, 2013) dan (Setiawati, 2014) menemukan bahwa ukuran Perusahaan berpengaruh positif pada manajemen laba. Watts and Zimmerman (1990) menyatakan dalam teori akuntansi positif, bahwa biaya politik meningkat seiring dengan meningkatnya ukurani perusahaani. Maka dapat dirumuskan hipotesis sebagai berikut:

$\mathrm{H}_{3}$ : Ukuran Perusahaan berpengaruh positif pada manajemen laba riil.

Berdasarkan teori keagenan (Jensen and Meckling, 1976), menjelaskan bahwa terjadi konflik antara pihak agent dan principal. Sesuai dengan bird in the hand theory pihak principal lebih menyukai pembagian dividen yang lebih besar dari pada capital gains. Perusahaan pada umumnya dapat membagikan dividen kepada para investor. Tujuan diterbitkan dividen ini adalah untuk menarik investor. Alat ukur yang digunakan dalam menentukan jumlah dividen yang dapat dibagikan adalah DPR (Dividend Payout Ratio). Berdasarkan hasil penelitian Budiasih (2009) menyatakan bahwa kebijakan dividen tidak berpengaruh 
I Wayan budi dan IGA.M Asri Dwija Putri. Pengaruh...

terhadap manajemen laba. Sedangkan menurut (Pasaribu, 2016) menyatakan bahwa kebijkan dividen berpengaruh signifikan terhadap manajemen laba. Hasil penelitian yang dilakukan (Putri, 2012) dan Dahayani (2017) menyatakan semakin tinggi DPR (Dividen Payout Ratio) berarti manajemen melakukan manajemen laba dengan income decreasing. Maka dapat dirumuskan hipotesis sebagai berikut: $\mathrm{H}_{4}$ : Kebijakan dividen berpengaruh positif pada manajemen laba riil.

\section{METODE PENELITIAN}

Penelitian ini merupakan penelitian kuantitatif asosiatif yaitu penelitian yang meneliti pengaruh suatu variabel terhadap variabel lainnya atau mengetahui hubungan antar variabel (Sugiyono, 2014:13). Lokasi penelitian ini dilakukan pada perusahaan manufaktur yang terdaftar di Bursa Efek Indonesia.Obyek penelitian yang dipilih peneliti adalah manajemen laba riil pada perusahaan manufaktur yang terdaftar di Bursa Efek Indonesia.

Kepemilikan institusional menunjukan persentase saham perusahaan yang dimiliki oleh institusi. Kepemilikan institusi dapat diukur dengan presentase jumlah saham yang dimiliki oleh investor institusional Kusumawati (2015).

$\mathrm{KI}=\frac{\text { jumlah saham kepemilikan institusi }}{\text { total saham kepemilikan perusahaan }} \times 100 \%$

Kepemilikan manajerial merupakan kepemilikan saham perusahaan oleh para manajemen. Kepemilikan manajerial dapat diukur dengan presentase jumlah saham yang dimiliki oleh manajemen (Apriada, 2013).

$\mathrm{KM}=\frac{\text { jumlah saham kepemilikan manajer }}{\text { total saham kepemilikan perusahaan }} \mathrm{X} 100 \%$

Ukuran Perusahaanadalah suatu skala dimana dapat diklasifikasikan menjadi perusahaan yang besar dan kecil (Kusumawardhani, 2012). Ukuran 
Perusahaanditunjukkan melalui log total aset. Ukuran Perusahaanmenurut (Jogiyanto 2016: 259) dapat dihitung dengan menggunakan rumus sebagai berikut.

Ukuran Perusahaan $=$ Log total aset

Kebijakan dividen merupakan keputusan apakah laba yang diperoleh perusahaan dapat dibagikan dalam bentuk dividen atau dalam bentuk modal guna untuk investasi masa mendatang. Rumus Dividend Payout Ratio adalah.

DPR $=\frac{\text { Dividen Per Lembar Saham }}{\text { Laba Per Lembar Saham }}$

Manajemen Laba merupakan merupakan tindakan yang menyimpang dari kegiatan bisnis normal, kegiatan ini dilakukan oleh manajer perusahaan untuk mencapai target laba yang ditetapkani (Roychowdhury, 2006). Tiga proksi dari manajemen laba riil adalah sebagai berikut:

Abn CFO merupakan manipulasii labaiyang dilakukanperusahaanmelalui alirankasoperasiyangi memilik aliran kas lebih rendah dari pada level normalnya.

$$
\mathrm{AbnCFO}=\frac{C F O t}{A t-1}-\left[a 1\left(\frac{1}{\log \cdot A t-1}\right)+\beta 1\left(\frac{S t}{A t-1}\right)+\beta 2\left(\frac{\Delta S t}{A t-1}\right)\right] .
$$

AbnPROD merupakan manajemen laba riil yang dilakukan melalui manipulasi biaya produksi, perusahaani yang memiliki biaya produksi yang lebih tinggi daripada level normalnya

$$
\begin{aligned}
& \text { AbnPROD }=\frac{P R O D t}{A t-1}-\left[a 1\left(\frac{1}{\log \cdot A t-1}\right)+\beta 1\left(\frac{S t}{A t-1}\right)+\beta 2\left(\frac{\Delta S t}{A t-1}\right)+\right. \\
& \left.\beta 3\left(\frac{\Delta S t-1}{A t-1}\right)\right]
\end{aligned}
$$


AbnDISEXP adalah manipulasi laba yang dilakukan perusahaan melalui biaya penelitian dan pengembangan, biaya iklan, biaya penjualan, biaya administrasi dan biaya umum

$$
\operatorname{AbnDISEXP}=\frac{\operatorname{DISEXP} t}{A t-1}-\left[a 1\left(\frac{1}{\log \cdot A t-1}\right)+\beta 1\left(\frac{S t}{A t-1}\right)\right]
$$

Menuru Pratiwi (2013), dan Sari (2015) untuk mencari nilai manajemen laba riil ketiga proksi tersebut dijumlahkan. Biaya produksi abnormal dikalikan dengan (-1) dengan tujuan untuk menyamakan arah.

$$
\mathrm{MLR}=\mathrm{AbnCFO}+\mathrm{AbnDISEXP}+(\mathrm{AbnPROD} \times(-1))
$$

Dalam penelitian ini yang menjadi populasi adalah perusahaan-perusahaan manufaktur yang terdaftar di BEI tahun 2013-2016.Metode penentuan sampel yang digunakan peneliti dalam penelitian ini adalah metode Purposive samplingmerupakan teknik pengambilan sampel dengan pertimbangan atau kriteria tertentu adapun kriteria sebagai berikut: 1) Perusahaan manufaktur yang terdaftar di BEI tahun 2013-2016. 2) Perusahaan manufaktur yang menerbitkan laporan keuangan tahunan untuk periode 31 Desember 2013-2016. 3) Perusahaan yang terdaftar di Bursa Efek Indonesia secara berturut-turut pada periode pengamatan 2013-2016. 4) Perusahaan menerbitkan laporan keuangan tahunan dinyatakan dalam rupiah. 5) Data yang tersedia lengakp terkait dengan variabel yang digunakan.

Berdasarkan kriteria tersebut jumlah observasi yang diperoleh untuk penelitian adalah sebanyak 11 perusahaan dengan 44 total obseravasi. Pada penelitian ini mempergunakan metode pengumpulan data observasi nonpartisipan. 
Dilakukan Uji Statistik Deskriptif, Uji Asumsi Klasik hingga Uji AnalisisRegresi LinearBergandayang menghasilkan persamaan sebagai berikut.

$\mathrm{Y}=\beta_{0}+\beta_{1} \mathrm{X}_{1}+\beta_{2} \mathrm{X}_{2}+\beta_{3} \mathrm{X}_{3}+\beta_{4} \mathrm{X}_{4+} \mathrm{e}$

Keterangan:

$\mathrm{Y} \quad=$ Manajemen Laba Riil

A $\quad=$ Nilai Intersep Konstanta

$\beta_{1}-\beta_{4}=$ Koefisieniregresiivariabeli $X_{1}, X_{2}, X_{3}$ dan $X_{4}$

$\mathrm{X}_{1} \quad=$ Kepemilikan Institusional

$\mathrm{X}_{2} \quad=$ Kepemilikan Manajerial

$\mathrm{X}_{3} \quad=$ Ukuran perusahaan

$\mathrm{X}_{4}=$ Kebijakan Dividen

$\varepsilon \quad=$ Error

\section{HASIL DAN PEMBAHASAN}

Setelah dilakukan observasi penelitian, perusahaan yang dapat dijadikan sampel sebanyak 11 perusahaan dengan total 44 sampel amatan yang ditunjukan dengan proses seleksi sebagai berikut.

Tabel 1.

Hasil Seleksi Pemilihan Sampel

\begin{tabular}{clc}
\hline No. & Keterangan & Jumlah \\
\hline 1. & Perusahaan manufaktur yang terdaftar di BEI pada periode 2013-2016. & 144 \\
2. & $\begin{array}{l}\text { Perusahaan manufaktur yang terdaftar di BEI yang tidak menerbitkan } \\
\text { laporan keuangan 31 Desember. }\end{array}$ & $(4)$ \\
3. & $\begin{array}{l}\text { Perusahaan manufaktur yang tidak terdaftar di BEI secara berturut-turut } \\
\text { pada periode 2013-2016. }\end{array}$ & $(17)$ \\
4. & $\begin{array}{l}\text { Perusahaan manufaktur yang yang menampilkan laporan keuangan tidak } \\
\text { dalam mata uang rupiah }\end{array}$ & $(25)$ \\
5. & $\begin{array}{l}\text { Perusahaan yan tidak mengungkapkan struktur kepemilikan } \\
\text { 6. }\end{array}$ & Perusahaan yang tidak mengungkapkan kebijakan dividen \\
& $\quad$ Total Sampel Pengamatan selama 4 tahun & $(27)$ \\
& $\quad$
\end{tabular}

Sumber: Data diolah, 2017

Statistik deskriptif digunakan untuk mengetahui jumlah sampel, nilai minimum, nilai maksimum, nilai rata-rata, dan standar deviasi dari masing-masing variabel. Dapat dijelaskan dalam tabel 2 sebagai berikut. 
Tabel 2.

Statistik Deskripstif Variabel-Variabel Penelitian

\begin{tabular}{lrrrrc}
\hline & N & Minimum & Maximum & \multicolumn{1}{c}{ Mean } & $\begin{array}{c}\text { Std. } \\
\text { Deviation }\end{array}$ \\
\hline$X_{1}$ (Kepemilikan Institusional) & 44 & 0,22478 & 0,96091 & 0,5979958 & 0,20589114 \\
X $_{2}$ (Kepemilikan Manajerial) & 44 & 0,00005 & 0,47522 & 0,0764746 & 0,14166969 \\
X $_{3}$ (Ukuran perusahaan) & 44 & 11,12640 & 14,41806 & 12,5695832 & 0,96783968 \\
X $_{4}$ (Kebijakan Dividen) & 44 & 0,04520 & 0,83330 & 0,3791364 & 0,21729810 \\
Y (Manajemen Laba Riil) & 44 & $-0,56600$ & 0,41727 & $-0,0773475$ & 0,21911119 \\
Valid N (listwise) & 44 & & & & \\
\hline
\end{tabular}

Sumber: Data diolah, 2017

Variabel Kepemilikan Institusional $\left(\mathrm{X}_{1}\right)$ memiliki nilai terendah (minimum) sebesar 0,22478 persen yang dimiliki oleh perusahaan Wismilak Inti Makmur Tbk pada tahun 2013, 2014 dan 2015, sedangkan nilai tertinggi (maksimum) sebesar 0,96091 persen yang dimiliki oleh perusahaan Sekar Laut Tbk pada tahun 2013, 2014 dan 2015, dengani rata-ratai (mean)i sebesari 0,59799 persen dan simpangan baku (standar deviasi) sebesar 0,2058 persen.

Variabel KepemilikanManajerial $\left(\mathrm{X}_{2}\right)$ memilikinilai terendah (minimum) sebesari 0,00004608 yang dibulatkan menjadi 0,00005 persen terdapat pada perusahaan Asahimas Flat Glass Tbk pada tahun 2013 hingga 2016, sedangkan nilai tertinggi (maksimum) sebesar 0,4752 persen yang dimiliki oleh perusahaan Wismilak Inti Makmur Tbk pada tahun 2013 dan 2014, dengani rata-ratai(mean) sebesari 0,0765 persen dan simpangan baku (standar deviasi) sebesar 0,1416 persen.

Variabel Ukuran Perusahaan $\left(\mathrm{X}_{3}\right)$ memiliki nilai terendah (minimum) sebesar 11,126 persen yang dimiliki oleh perusahaan Lionmesh Prima Tbk pada tahun 2015, sedangkan nilai tertinggi (maksimum) sebesar 14,418 persen yang dimiliki oleh perusahaan Astra International Tbk pada tahun 2016, dengan rata- 
rata (mean) sebesar 12,569 persen dan simpangan baku (standar deviasi) sebesar 0,967 persen.

Variabel Kebijakan Dividen $\left(\mathrm{X}_{4}\right)$ memiliki nilai terendah (minimum) sebesar 0,0452 persen yang dimiliki oleh perusahaan Lion Metal Works Tbk pada tahun 2015, sedangkan nilai tertinggi (maksimum) sebesar 0,8333 persen yang dimiliki oleh perusahaan Trias Sentosa Tbk pada tahun 2013, dengan rata-rata (mean) sebesar 0,379 persen dan simpangan baku (standar deviasi) sebesar 0,2172 persen.

Variabel Manajemen Laba Riil (Y) memiliki nilai terendah (minimum) sebesar -0,566 persen yang dimiliki oleh perusahaan Lionmesh Prima Tbk pada tahun 2014, sedangkan nilai tertinggi (maksimum) sebesar 0,417 persen yang dimiliki oleh perusahaan Mandom Indonesia Tbk pada tahun 2013, dengan ratarata (mean) sebesar -0,077 persen dan simpangan baku (standar deviasi) sebesar 0,219 persen.

Selanjutnya dilakukan uji asumsi klasik yang meliputi uji normalitas, uji autokorelasi, uji multikolinearitas dan uji heteroskedastisitas untuk mengetahui apakah data dalam penelitian yang dilakukan telah lolos dari asumsi klasik. Nilaii Asympi. Sigi. (2-tailed) dari modeli persamaani yang diuji sebesari0,997 lebih besar dari 0,05 . Hal ini menunjukkan data yang digunakan dalam penelitian ini telah berdistribusi normal.

Berdasarkan hasili ujii autokorelasii, nilai dw yang dihasilkan sebesar 1,865. Oleh karena jumlah $\mathrm{n}=44$ dan $\mathrm{k}=4$, makai diperoleh nilai du 1,720. 
NilaiDW 1,865 lebih besar dari batas atas (du) yakni 1,720 dan kurang dari (4-du) $4-1,720=2,280$ dapat disimpulkan bahwa tidak terdapat autokorelasi.

Ujii selanjutanya yaitu uji multikolinearitas. Uji multikolinearitas bertujuan untuk menguji apakah model regresi ditemukan adanya korelasi antara variabel bebas. Masing-masing variabel bebas memiliki nilai tolerance yaitu 0,747 (kepemilikan institusional), 0,696 (kepemilikan manajerial), 0,510 (ukuran perusahaan) dan 0,769 (kebijakan dividen) lebih besar dari 10\% $(0,10)$ dan nilai VIF masing-masing variabel bebas tersebut yaitu 1,339 (kepemilikan institusional), 1,437 (kepemilikan manajerial), 1,962 (ukuran perusahaan) dan 1,300 (kebijakan dividen) lebih kecil dari 10. Berdasarkan nilai tolerance dan VIFi dari masing-masingvariabelbebas, maka dapat disimpulkan bahwa model persamaan regresi bebas dari gejala multikolinearitas.

Uji asumsi klasik yang digunakan selanjutnya adalah uji heteroskedastisitas nilai signifikansi dari variabel kepemilikan institusional, kepemilikan manajerial, ukuran perusahaan, dan kebijakan dividen, masingmasingi sebesari 0,$408 ; 0,409 ; 0,269$ dan 0,694 . Nilai tersebut lebih besar dari 0,05 yang berarti tidak terdapatpengaruh antara variabel bebas terhadap absolute residual. Dengan demikian, model yang dibuat tidak mengandung gejala heteroskedastisitas.

Pada Tabel 3 berikut ini dapat dijelaskan rekapitulas hasil analisis regresi linier berganda. 
Tabel 3.

Rekapitulasi Hasili Analisis Regresi Linear Berganda

\begin{tabular}{lccc}
\hline \multicolumn{1}{c}{ Variabel } & $\begin{array}{c}\text { Nilai Koefisien } \\
\text { Regresi }\end{array}$ & t hitung & $\begin{array}{c}\text { Nilai } \\
\text { Signifikansi }\end{array}$ \\
\hline Constant & 0,364 & 1,840 & 0,073 \\
Kepemilikan Institusional $\left(\mathrm{X}_{1}\right)$ & $-0,062$ & $-0,991$ & 0,328 \\
Kepemilikan Manajerial $\left(\mathrm{X}_{2}\right)$ & $-0,115$ & $-1,769$ & 0,085 \\
Ukuran Perusahaan $\left(\mathrm{X}_{3}\right)$ & 0,491 & 6,494 & 0,000 \\
Kebijakan Dividen $\left(\mathrm{X}_{4}\right)$ & 0,682 & 11,076 & 0,000 \\
R Square & & & 0,886 \\
Adjusted $R$ Square & & & 0,875 \\
F Statistik & & & 76,039 \\
Signifikansi & & & 0,000 \\
\hline Sumber: Data dian
\end{tabular}

Sumber: Data diolah, 2017

Berdasarkan hasil yang diperoleh dari rekapitulasi hasil analisis regresi linear berganda berdasarkan pada hasil analisis koefisien regresi pada Tabel 4 adalah sebagai berikut:

$$
Y=0,364-0,062 X_{1}-0,115 X_{2}+0,491 X_{3}+0,682 X_{4}+e
$$

Nilai konstanta sebesar 0,364 artinya jika nilai variabel kepemilikan institusional, kepemilikan manajerial, ukuran perusahaan, dan kebijakan dividen dianggap konstan (tidak ada perubahan) maka nilai manajemen laba riil sebesar 0,364. Nilai koefisien variabel kepemilikan institusional sebesar $-0,062$ artinya jika nilai variabel kepemilikan institusional mengalami kenaikan 1 persen, maka variabel manajemen laba riil mengalami penurunan sebesar $6,2 \%$ dengan asumsi variabel bebas lainnya konstan. Nilai koefisien variabel kepemilikan manajerial sebesar $-0,115$ artinya jika nilai variabel kepemilikan institusional mengalami kenaikan 1 persen, maka variabel manajemen laba riil mengalami penurunan sebesar $11,5 \%$ dengan asumsi variabel bebas lainnya konstan. Nilai koefisien variabel ukuran Perusahaansebesar 0,491 artinya jika nilai variabel kepemilikan institusional mengalami kenaikan 1 persen, maka variabel manajemen laba riil 
mengalami kenaikan sebesar 49,1\% dengan asumsi variabel bebas lainnya konstan. Nilai koefisien variabel kebijakan dividen sebesar 0,682 artinya jika nilai variabel kepemilikan institusional mengalami kenaikan 1 persen, maka variabel manajemen laba riil mengalami kenaikan sebesar $68,2 \%$ dengan asumsi variabel bebas lainnya konstan.

Berdasarkan hasil uji kesesuaian model pada Tabel 4 di atas, dapat dilihat bahwa nilai dari uji F sebesar 76,039 dan nilai $p$-value (Sig. F) yakni 0,000 lebih kecil dari nilai $\alpha=0,05$. Hal ini menunjukkan bahwa model persamaan dalam penelitian ini layak untuk digunakan sebagai alat analisis untuk menguji pengaruh variabel independen pada variabel dependen.

Adapun nilai dari adjustedR square pada penelitian ini telah disajikan pada Tabel 4. Berdasarkan pada Tabel 4 diatas, dapat dilihat bahwa nilai dari adjusted $R^{2}$ sebesar 0,886dimana memiliki arti bahwa 88,6\% variasii manajemen laba riil dipengaruhi oleh variasi kepemilikan institusionali, kepemilikani manajerial, ukuran perusahaani, dan kebijakan dividen sedangkan sisanya sebesar $11,4 \%$ dijelaskan oleh faktor lain yang tidak dimasukkan ke dalam model

Uji $\mathrm{t}$ dilakukan untuk mengetahui seberapa besar pengaruh variabel independen terhadap variabel dependen secara parsial. Uji t dilakukan dengan membandingkan hasil nilai signifikansi dengan $\alpha=0,05$. Berdasarkan hasil analisis pengaruh kepemilikan institusionalpada manajemen laba riil diperoleh nilai signifikansi sebesari 0,328 dengani nilaii koefisieni regresii sebesari -0,062. Nilaii signifikansi 0,328>0,05 mengindikasikani bahwai $\mathrm{H}_{0}$ diterima dan $\mathrm{H}_{1}$ 
ditolak. Hasil ini mempunyaii arti bahwaikepemilikan institusional tidak berpengaruh pada manajemen labariil.

Berdasarkan hasil analisis pengaruhi kepemilikan manajeria lpada manajemen labariil diperoleh nilai signifikansi sebesar 0,085 dengan nilai koefisien regresi sebesar -0,115. Nilai signifikansi $0,085>0,05$ mengindikasikan bahwa $\mathrm{H}_{0}$ diterima dan $\mathrm{H}_{2}$ ditolak. Hasil ini mempunyai arti bahwa kepemilikan manajerial tidak berpegaruh pada manajemen labariil. Berdasarkani hasil analisis pengaruhiukurani perusahaanpada manajemen labariil diperoleh nilai signifikansi sebesari 0,000 dengan nilai koefisien regresi sebesar 0,491. Nilai signifikansi $0,000<0,05$ mengindikasikan bahwa $\mathrm{H}_{0}$ ditolak dan $\mathrm{H}_{3}$ diterima. Hasil ini mempunyai arti bahwa ukurani perusahaani berpengaruh pada manajemen labariil.

Berdasarkan hasil analisis pengaruh kebijakan dividenpada manajemen laba riil diperoleh nilai signifikansi sebesar 0,000 dengan nilaii koefisieni regresi sebesar 0,682 . Nilai signifikansi $0,000<0,05$ mengindikasikan bahwa $\mathrm{H}_{0}$ ditolak dan $\mathrm{H}_{4}$ diterima. Hasil ini mempunyai arti bahwa kebijakan dividen berpengaruh pada manajemen labariil.

Jensen and Meckling (1976) menyatakan bahwa kepemilikan institusional memiliki peranan penting dalam mengurangi konflik keagenan. Kepemilikan institusional merupakan pemegang saham mayoritas dalam perusahaan. Penyebab tidak signifikannya hubungan ini karena dalam penelitian ini tidak membedakan ukuran institusi dan ukuran kepemilikan institusi, sehingga seluruh kepemilikan institusi dianggap memiliki pengaruhi yang sama. Menurrut Suriyani (2015) institusi kecil kurang aktif dalam memberikan tekanan pada aktivitas manajemen 
dibandingkan dengan institusi yang lebih besar. Hasil penelitian ini mendukung penelitian Nugroho (2013), Mahariana (2014), Hadayanti (2014), Gea (2014), Effendi (2013), Putri (2012) dan Agustia (2013). Penelitian ini menunjukkan bahwa kepemilikan institusional tidak memiliki kemampuan untuk mengendalikan pihak manajemen sehingga tidak dapat mengurangi praktek manajemen labariil.

Jensen and Meckling (1976) menyatakan bahwa kepemilikan saham manajerial dalam perusahaan mendorong untuk menciptakan kinerja perusahaan secara optimal. Semakin besar proporsi kepemilikan manajerial pada perusahaan, maka manajemen cenderung giat untuk meningkatkan nilai perusahaan.Hasil statistik deskriptif terlihat bahwa kepemilikan manajerial di Indonesia sangat kecil yaitu rata-rata di bawah 5\%. Hal ini menyebabkan manajer melakukan tindakan manajemen laba. Hasil penelitian ini mendukung penelitian Santana (2016), Gea (2014), Agustia (2013) yang menyatakan bahwa potensi munculnya konflik dalam hubungan agensi sangat besar, yaitu ketika manajemen perusahaan memiliki kurang dari 100\% saham milik perusahaan maka potensi konflik itupun muncul.

Gunawan (2015) menyatakan bahwa perusahaan besar memiliki dorongan yang lebih besar untuk melakukan perataan laba (salah satu bentuk manajemen laba) dibandingkan dengan perusahaan kecil. Rahmani (2013) dan Setiawati (2016), yang menyatakan bahwa ukuran Perusahaan berpengaruh pada manajemen laba riil. Hal ini berarti perusahaan besar cenderung memiliki dorongan yang lebih besar untuk melakukan manajemen laba. Watts and 
Zimmerman (1990) menyatakan bahwa dalam teori akuntansi positif, biaya politik meningkat seiring dengan meningkatnya ukuran perusahaan.

Kebijakan dividen adalah keputusan tentang seberapa banyak laba saat ini yang dapat dibayarkan sebagai dividen daripada ditahan untuk diinvestasikan kembali dalam perusahaan. Dalam penelitian ini memberikan bukti bahwa kebijakan dividen suatu sumber konflik antara pemegang saham dan manajemen dapat termotivasi untuk melakukani tindakani manajemeni laba. Semakin besar Dividen Payout Ratio (DPR) maka manajemen melakukan manajemen laba dengan menurunkan laba (income decresing). Hasil penelitian ini mendukung teori keagenan sebagai teori utama yang mendasari penelitian ini. Teori keagenan (Jensen and Mckling, 1976) menyatakan bahwa antara manajemen dan pemegang saham terbukti menimbulkan konflik karena kedua belak pihak, manajemen maupun prinsipal mengharapak keuntungan yang maksimal. Penelitian ini juga mendukung penelitian dari Putri (2012), Dahayani (2017) dan Widanaputra (2010).

Implikasi dari hasil penelitian ini mencakup dua hal, yaitu implikasi teoretis dan praktis. 1) Implikasi Teoretis, Penelitian yang dilakukan diharapkan dapat memberikan kontribusi mengenai pengaruh struktur kepemilikan, ukuran Perusahaandan kebijkan dividen pada manajemen laba riil yang dilakukan pada sektor manufaktur yang terdaftar di Bursa Efek Indonesia (BEI) dari tahun 20132016. Hasil uji penelitian ini ditemukan dua dari empat variabel independen berpengaruh signifikan pada manajemen laba riil. Variabel independen yang berpengaruh signifikan pada manajemen laba riil adalah ukuran Perusahaandan 
kebijakan dividen. 2) Implikasi Praktis, Penelitian ini memberikan implikasi bagi investor sebagai pertimbangan dan pengetahuan mengenai kebijakan yang dapat diambil oleh manajemen perusahaan. Hasil penelitian ini diharapkan dapat membantu perusahaan dalam mempertimbangkan pengambilan keputusan keuangan yang dapat diambil oleh manajemen perusahaan. Pihak investor dapat memperhatikan faktor-faktor lain dalam berinvestasi karena dalam penelitian ini terdapat faktor lain yang dapat mempengaruhi terjadinya manajemen laba riil.

\section{SIMPULAN}

Berdasarkani hasil penelitiani yang diperoleh melalui pengujiani statistik serta pembahasan seperti yang telah diuraikan, maka dapat disimpulkan bahwa: 1) Kepemilikan institusional tidak berpengaruh signifikan pada manajemen laba riil, hal ini dapat terjadi karena investor institusional yang memiliki jumlah saham yang besar, memiliki insentif yang kuat untuk mengembangkan informasi privat. 2) Kepemilikan manajerial tidak berpengaruh signifikan pada manajemen laba riil, hal ini disebabkan oleh kepemilikan manajerial perusahaan di Indonesia sangat kecil dengan rata-rata di bawah 5\%. 3) Ukuran Perusahaan berpengaruh signifikan pada manajemen laba riil, hal ini disebabkan oleh perusahaan besar cenderung memiliki dorongan yang lebih besar untuk melakukan manajemen laba riil.4) Kebijakan dividen berpengaruh signifikan pada manajemen laba riil, hal ini disebabkan karena kebijakan dividen sebagai sumber konflik antara prinsipal dan agen dapat termotivasi untuk melakukan tindakan manajemen laba. Adapun saran dalam penelitian ini adalah sebagai berikut: 1) Perusahaan yang terdaftar disektor manufaktur sebaiknya menghindari praktek manajemen laba rii dan semaksimal 
mungkin untuk meningkatkan kualitas laba perusahaan. 2) Para investor dan calon investor diharapkan mampu menyimak laporan keuangan yang dipublikasikan perusahaan setiap tahunnya agar mengetahui indikasi terjadinya praktek manajemen laba riil. 3) Peneliti selanjutnya dapat memperluas objek penelitian baik dari segi bidang usaha, periode penelitian, maupun jumlah variabel penelitian yang dapat mempengaruhi praktek manajemen laba riil seperti leverage dan profitabilitas serta memasukkan variabel pemoderasi penerapan Good Corporate Governance.

\section{REFERENSI}

Agustia, Dian. 2013. Pengaruh Faktor Goodi Corporate Governance, Free Cash Flow, dan Leverage terhadap Manajemen Laba. Jurnal Akuntansi dan Keuangan, 15 (1), hal. 27-42.

Budiasih, I.G.A.N. 2009. Faktor-Faktor yang Mempengaruhi Praktik Perataan Laba. Jurnal Akuntansi dan Bisnis, 4, hal. 1-14.

Dahayani, Ni Ketut Sri, I Ketut Budiartha, dan I Made Sadha Suardikha. 2017. Pengaruh Kebijakan Dividen pada Manajemen Laba Dengan Good Corporate Governance Sebagai Moderasi. E-Jurnal Ekonomi dan Bisnis Universitas Udayana. 6 (4), hal. 1395-1424.

Effendi, Sofyan Dan Daljono. 2013. Pengaruh Corporate Governance dan Kualitas Auditor terhadap Manajemen Laba. Diponegoro Journal of Accounting, 2 (3), hal. 1-14.

Gea, Marinus. 2014. Peran GCG dan Struktur Kepemilikan Dalam Mendeteksi Manajemen Laba Melalui Discretionary Revenue. Jurnal Tekun, 5 (2), hal. 202-217.

Gunawan, I Ketut, Nyoman Ari Surya Darmawan dan Gusti Ayu Purnamawati. 2015. Pengaruh Ukurani perusahaani, Profitabilitas, dan Leverage Terhadap Manajemen Laba pada Perusahaan Manufaktur yang Terdaftar Di Bursa Efek Indonesia (BEI). E-Journal S1 Ak Universitas Pendidikan Ganesha Jurusan Akuntansi Program S1, 3 (1), hal. 1-10.

Hidayanti, Ery, dan Ratna Widjayanti Dahniari Paramita. 2014. Pengaruh Good Corporate Governance Terhadap Praktek Manajemeni Laba Riil pada Perusahaan Manufaktur. Jurnal WIGA. 4 (2), hal. 1-16 
Hsu, Ming Feng dan Shiow Ying Wen. 2015. The Influence of Corporate Governance in Chinese Companies on Dicretionary Accrual and Real Earnings Management. Asian Economic and Financial Review, 5 (3), pp. 391-406.

Jao, R. dan Pagalung, G. 2011. Corporate Governance, Ukurani perusahaani, dan Leverage terhadap Manajemen Laba Perusahaan Manufaktur Indonesia. Jurnal Akuntansi \& Auditing, 8 (1), hal. 1-94.

Jensen, Michael C. and W.H Meckling. 1976. Theory of Thei Firm: Managerial Behaviour, Agency Cost and Ownership Structure. Journal of Financial Economics, 3, pp. 305-360.

Jogiyanto. 2006. Teori Portofolio dan Analisis Investasi. Yogyakarta: BPFE.

Kamran, and Attaullah Shah. 2014. The Impact of Corporate Governance and Ownership Structure on Earnings Management Practices: Evidence from Listed Companies in Pakistan. The Lahore Journal of Economics, 19 (2), pp. $27-70$.

Kusumawardhani, Indra. 2012. Pengaruh Corporate Governance, Struktur Kepemilikan, dan Ukuran Perusahaanterhadap Manajemen Laba. Jurnal Akuntansi dan Sistem Teknologi Informasi, 9(1), hal. 41-54.

Kusumawati, Eny, Rina Trisnawati, dan Ahmad Mardalis. 2015. Pengaruh Corporate Governance terhadapiManajemen labaRiil. The University Research Coloquium. hal. 339-350.

Mahariana, I Dewa Gede Pingga, dan I Wayan Ramantha. 2014. Pengaruh Kepemilikan Manajerial dan Kepemilikan Institusional pada Manajemen Laba Perusahaan Manufaktur Di Bursa Efek Indonesia. E-Jurnal Akuntansi Universitas Udayana, 7 (2), hal. 519-528.

Muliati, Ni Ketut. 2011. Pengaruh Asimetri Informasi dan Ukuran Perusahaanpada Praktik Manajemen laba di Perusahaan Perbankan yang terdaptar di Bursa Efek Indonesia. Tesis, Program Magister Program Studi Akuntansi Program Pascasarjana Universitas Udayana, Denpasar.

Nugroho, Joko Purwanto. 2013. Analisis Pengaruh Kepemilikan Manajerial dan Kepemilikan Institusional terhadap Manajemen Laba. Jurnal Bisnis dan Ekonomi, 4 (2), hal. 177-188.

Octavia, Meliana, Imam Subekti dan Endang Mardiati. 2015. Faktor- Faktor yang Mempengaruhi Praktik Manajemen Laba Riil-Biaya Diskrsioner. International Journal Of Social And Local Economic Governance (IJLEG), 1 (2), hal. 108-115. 
Pasaribu, Rowland Bismark Fernando dan Esty Dwi Widyastuty. 2016. Pengaruh Konservatisme Akuntansi, Kepemilikan Manajerial, Kebijakan Dividen, Ukurani perusahaani, Leverage, Price Earning Ratio, Price To Book Value, dan Earning Per Share terhadap Manajemen Laba. Jurnal Ekonomi dan Bisnis, 10 (2), hal. 71-87.

Pratiwi, Yudhitya Dian dan Wahyu Meiranto. 2013. Pengaruh Penerapan Corporate Governance terhadap Earnings Management Melalui Aktivitas Riil. Diponogor Journal of Accounting, 2 (3), hal. 1-15.

Putri, I.G.A.M Asri Dwija. 2011. Dampak Good Corporate Governance dan Budaya Organisasi pada Pengaruh Kebijakan Dividen terhadap Manajemen Laba serta Konsekuensinya pada Nilai Perusahaan. Disertasi. Fakultas Ekonomi dan Bisnis Universitas Brawijaya.

Putri, I.G.A.M Asri Dwija. 2012. Pengaruh Kebijakan Dividen dan Good Corporate Governance terhadap Manajemen Laba. Buletin Studi Ekonomi, 17 (2), hal. 157-171.

Rahmani, Samira and Akbari Mir Askari. 2013. Impact of Firm Size and Capital Structure on Earnings Management: Evidence from Iran. World of Sciences Jorunal. hal. 2307-3071.

Rahmawati. (2012). Teori Akuntansi Keuangan. Yogyakarta: Graha Ilmu.

Roychowdhury, S. 2006. Earningi Management Throughi Real Activities Manipulation. Journali ofi Accounting and Economics, 42. Pp. 335-370.

Santana, Dewa Ketut Wira dan Made Gede Wirakusuma. 2016. Pengaruh Perencanaan Pajak, Kepemilikan Manajerial dan Ukuran Perusahaanterhadap Praktek Manajemen Laba. E-Jurnal Akuntansi Universitas Udayana, 14 (3), hal. 1555-1583.

Sari, Gustin Padwa. 2015. Manipulasi Laba Riil: Upaya Untuk Menghindari Kerugian. Akuisisi, 11 (2), hal. 35-43.

Setiwati, Loh Wenny, dan Lieany. 2016. Analisis Pengaruh Perjanjian Utang, Kepemilikan Institusional, dan Ukuran PerusahaanTerhadap Manajemen Laba Riil pada Perusahaan Manufaktur yang Terdaftar di Bursa Efek Indonesia. Jurnal Akuntansi, 9 (2), hal. 172-197.

Subekti, Imam. 2012. Accrual and Real Earnings Management. Jurnal of Econoics, Business, and Accountancy, 15(3), pp. 443-456.

Suriyani, Putu Putri, Gede Adi Yuniarta, dan Ananta Wikrama T.A. 2015. FaktorFaktor yang Mempengaruhi Manajemen Laba (Studi Empiris pada Perusahaan Manufaktur yang terdaftar Di BEI Periode Tahun 2008-2013), 3 (1), hal. 1-11. 
Susanto, Yulius Kurnia and Arya Pradipta. 2016. Corporate Governance and Real Earnings Management. International Journal of Business, Economics and Law, 9 (1), pp. 17-23.

Utari, Ni Putu Linda Ayu dan Maria M. Ratna Sari. 2016. Pengaruh Asimetri Informasi, Leverage, Kepemilikan Manajerial dan Kepemilikan Institusional pada Manajemen Laba. E-Jurnal Akuntansi Universitas Udayana, 15 (3), hal. 1886-1914.

Vajriyanti, Eva. 2015. PengaruhiManajemen labaRiil pada Nilai Perusahaan dengan Good Corporate Governance Sebagai Variabel Pemoderasi. Diss. Universitas Udayana.

Watts, R. L. and J. L. Zimmerman. (1990). Positive Accounting Theory A Ten Year, The Accounting Review, pp. 131-156.

Wiagustini, Ni Luh Putu. 2014. Manajemen Keuangan. Denpasar: Udayana University Press.

Widanaputra, A A G P. 2010. Pengaruh Konflik Keagenan Mengenai Kebijakan Dividen terhadap Konservatisme Akuntansi. Journal Aplikasi Manajemen, 8 (2), hal. 379-390.

Wijayanti, Herlin, Soni Agus Irwandi, dan Nurmala Ahmar. Pengaruhi Manajemen Labai Riil terhadap Kinerja Perusahaan Dengan Pendekatan Arus Kas Operasi. Jurnal Economia, 1 (1), hal. 11-23.

Wiranata, Yulius Ardy dan Yeterina Widi Nugrahanti. 2013. Pengukuran Struktur Kepemilikan terhadap Profitabilitas Perusahaan Manufaktur di Indonesia. Jurnal Akuntansi dan Keuangan, 15 (1), hal. 1-16. 